University of Zurich

Department of Economics

Working Paper Series

ISSN 1664-7041 (print)

ISSN 1664-705X (online)

Working Paper No. 270

\title{
The Effect of Peer Gender on Major Choice
}

\author{
Ulf Zölitz and Jan Feld
}

First version: November 2017

This version: August 2018 


\title{
The Effect of Peer Gender on Major Choice*
}

\author{
[August 2018]
}

\author{
Ulf Zölitz \\ (University of Zurich)
}

\author{
Jan Feld \\ (Victoria University of Wellington)
}

\begin{abstract}
This paper investigates how the peer gender composition in university affects students' major choices and labor market outcomes. Women who are randomly assigned to more female peers become less likely to choose male-dominated majors, and they end up in jobs in which they work fewer hours and earn less. Men become more likely to choose male-dominated majors after having had more female peers, although their labor market outcomes are not affected. Our results suggest that the increasing female university enrollment over recent decades has paradoxically contributed to the occupational segregation among university graduates that persists in today's labor market.
\end{abstract}

Keywords: peer effects, major choice, gender composition

JEL classification: I21, I24, J24

\footnotetext{
*We thank Massimo Anelli, Anne Brenøe, Luke Chu, Harold Cuffe, Johannes Hermle, Andrew Hill, Simon Jäger, Jason Lindo, Alfredo Paloyo, Chris Roth, Nicolas Salamanca, Petra Thiemann, and seminar participants at Bocconi, Copenhagen Business School, IZA, Oxford University and the University of Zurich for helpful discussions and comments. We thank Sophia Wagner for providing outstanding research assistance. Ulf Zölitz: University of Zurich and IZA. Department of Economics and Jacobs Center for Productive Youth Development, Schönberggasse 1, 8001 Zurich. ulf.zoelitz@econ.uzh.ch. Jan Feld: Victoria University of Wellington and IZA. Victoria University of Wellington, School of Economics and Finance, 23 Lambton Quay, Pipitea, Wellington 6011, jan.feld@vuw.ac.nz.
} 


\section{Introduction}

Gender differences in major choice are an important determinant of the gender wage gap. Men are more likely than women to specialize in science and math-intensive fields, which lead to better-paid jobs in the labor market (OECD, 2016). Major choice has a causal effect on future earnings (e.g. Altonji, Arcidiacono, and Maurel, 2016; Kirkeboen, Leuven, and Mogstad, 2016) and between 10 and 50 percent of the gender wage gap can be explained by gender differences in major choice (Brown and Corcoran, 1997; Daymont and Andrisa, 1984; Gerhart 1990; Machin and Buhani, 2003).

For both men and women, choosing a major is difficult. When entering university, many students do not know which subjects they will perform well in and which subjects they will enjoy. This uncertainty about their ability and preferences is reflected in a significant share of students switching majors. ${ }^{1}$ In order to accommodate this uncertainty, universities typically grant students an initial period to become familiar with the university environment before requiring that they specialize further. During this orientation period, one important factor in students' social environment is their university peers. Students usually spend a substantial amount of time with their peers within and outside the classroom, and these peer interactions may influence students' preferences for and ability to perform well in a specific major. ${ }^{2}$

In this paper, we investigate how the peer gender composition in university affects men's and women's major choice and labor market outcomes. Previous research shows that peer gender can affect performance (e.g. De Giorgi, Pellizzari, and Woolston, 2012; Hill, 2015,

\footnotetext{
${ }^{1}$ Two studies on major-switching behavior model major choice as a dynamic process in which students learn about the characteristics of their major and their abilities. Kugler, Tinsley, and Ukhaneva (2017) study major switching at a large private US university where $12 \%$ of students who graduate switch their major at least once. They find that major switching is often a response to low grades, and women are particularly responsive to low performance in STEM majors. Astorne-Figari and Speer (2017) focus on another US university where 43\% of students who graduate switch major at least once. They find also find that low grades predict major switching and students switch to majors that "look like them" in terms of demographic characteristics.

${ }^{2}$ University instructors are another aspect in the university environment that may affect students' specialization choices. Carrell et al. (2010) show that female instructors in STEM increase women's likelihood of graduating with a STEM degree. Bettinger and Long (2005) also find that instructor gender affects women's major choice.
} 
2017; Hoxby, 2000; Lavy and Schlosser, 2011; Whitmore, 2005). These effects on performance may translate into different major choices, especially if peer effects differ by gender and subject. At the same time, there is evidence that gender composition affects the classroom environment and that a higher proportion of female students leads to a better atmosphere and less conflict (Figlio, 2007; Lavy and Schlosser, 2011; Oosterbeek and van Ewijk, 2014). Such a change in atmosphere may influence the subjects that men and women enjoy and want to major in.

In order to study the effect of peer gender on major choice, we use data from a Dutch business school. As at many other European universities, students at this business school first take a set of compulsory courses before further specializing and choosing a major. Within each of these courses, students are randomly assigned to teaching sections of up to sixteen students, with whom they spend most of their contact hours. Random assignment to sections within compulsory courses thus gives us exogenous variation in students' peers, which we exploit to estimate the effect of peer gender. We further conducted an online and telephone survey of graduates that allows us to test whether the effects of peer gender translate into different labor market outcomes.

Our short-run results show that peer gender affects major choice. Women exposed to a higher proportion of female peers become less likely to major in math-intensive, maledominated majors, such as Finance and IT Management, and more likely to major in femaledominated majors such as Marketing and Organization. These effects are economically significant. Having 10-percentage-points-more female peers in a given section reduces women's probability of choosing a male-dominated major by 0.8 percentage points, reflecting an 8 percent decrease from the baseline. By contrast, men choose more male-dominated and fewer female-dominated majors after exposure to more female peers. 
Our longer-run results show that peers have persistent effects beyond university graduation. Women who had more female peers end up in jobs where they earn less, but they also work fewer hours and report marginally higher job satisfaction. For women, the overall welfare effect of having more female peers is therefore not obvious. Men's labor market outcomes are not significantly affected by peer gender. Taken together, our results suggest that having more female peers increases occupational segregation by gender among university graduates.

To explore potential mechanisms, we test how peers influence students' grades and course evaluations. Because different introductory courses prepare students for different majors, we allow the influence of peers to differ by how math-intensive a course is. We find that having more female peers increases women's grades in nonmathematical courses but not in mathematical courses. Therefore, women who had more female peers have more reason to believe that they would perform better in less mathematical, female-dominated majors. These women also evaluate course quality and the group interaction more positively in nonmathematical courses, suggesting that their preferences for subjects have also changed. For men, the gender composition does not affect how they perceive course quality or group interaction. However, they achieve relatively higher grades after having had more female peers in mathematical courses, thus giving them a reason to choose math-intensive, male-dominated majors.

At present, we know little about the effect of the gender of university peers on major choice. ${ }^{3}$ Two studies focusing on the effect of peer gender on performance also test whether peer gender affects specialization choices. Hill (2017) exploits cohort-year variation in gender

\footnotetext{
${ }^{3}$ While not studying the impact of peer gender, two other papers have looked at how university peers affect major choice. Sacerdote (2001) exploits random assignment of students to college dorms and finds no evidence that roommates affect major choice. By contrast, De Giorgi, Pellizzari, and Woolston (2010) exploit random assignment to university classes using an identification strategy based on partially overlapping peer groups to show that peer effects in major choice exist.
} 
and finds that men's graduation rates increase after having had more female peers. In an additional analysis, he reports that having more female peers leads to fewer women graduating in STEM majors. However, this result only holds in specifications that include time trends. Booth, Cardona-Sosa, and Nolen (2013) show that women perform better when randomly assigned to a single-sex class in an introductory economics course. They find no statistically significant effect of single-sex classes on subsequent choices of technical courses, which may be due to the relatively small sample size of 400 observations and the resulting lack of statistical power.

Two other related studies exploit cohort variation to estimate the effect of high school peers' gender on major choice. ${ }^{4}$ Brenøe and Zölitz (2017) show that female students with a larger proportion of female peers in high school are less likely to complete a university STEM degree and are more likely to complete a degree in health studies. Anelli and Peri (2017) show that male high school students become more likely to choose male-dominated college majors when they were in cohorts with less than 20 percent female peers. They further find no significant differences in graduation rates or wages after college graduation. ${ }^{5}$

Our study differs in a number of important aspects from studies looking at how high school peers affect university major choice. Students in our setting have already committed to studying business or economics and must choose among a narrower set of university majors. ${ }^{6}$ We focus on peer interaction in the university classroom in which students study subjects

\footnotetext{
${ }^{4}$ In another related study, Schneeweis and Zweimueller (2012) exploit cohort variation in primary schools to study the effect of peer gender on secondary school choice. They find that girls with more female peers are more likely to enroll in male-dominated school types.

${ }^{5}$ Another related branch of literature investigates the reasons for gender differences in major choice. Zafar (2013) uses survey data on subjective expectations and finds that the main driver for differences in major choice is differences in preferences, especially about enjoying course work. Wiswall and Zafar (2017) use a hypothetical choice experiment and find that women have a higher willingness-to-pay for job flexibility and job stability and men have a higher willingness-to-pay for earnings growth. See also Kahn and Ginter (2017) for a comprehensive review on women and STEM.

${ }^{6}$ These majors mimic the gender segregation in the labor market as they substantially differ in the share of female students (20-60 percent) and mean annual earnings of graduates $(€ 36,000-52,000)$. Majors that are more popular with women are also less mathematical and associated with lower earnings.
} 
related to their potential majors. Such an environment is arguably more relevant in shaping students' subject-specific ability and preferences. In contrast, high school peers might be more likely to influence university major choices for nonacademic reasons, such as wanting to study in the same city - see Anelli and Peri (2017) for evidence on the role of high school friend networks in university major choice.

Taken together, we make three main contributions to the existing literature. First, we are the first to estimate the effect of peer gender on major choice using random assignment to peer groups. Second, we provide evidence on the longer-run labor market consequences of university peers. Because we can link administrative university data to survey data on graduates' labor market outcomes, we can test whether peer effects persist beyond university or fade out. Third, and more broadly, our paper contributes to a better understanding of how the social environment shapes gender differences in educational choices and labor market outcomes. The continuous increase in female university enrollment over recent decades has mechanically increased the proportion of female peers at university. This changing peer environment and its effect on students' specialization may contribute to explaining why occupational segregation by gender persists, despite the grand gender convergence that we have witnessed over the last century (Goldin, 2014).

\section{Institutional Environment and Summary Statistics}

\subsection{Institutional Environment}

The business school is located in the Netherlands and has about 4,300 students enrolled in bachelor's, master's and $\mathrm{PhD}$ programs. We focus our analysis on the bachelor's study programs Business and Business Economics, where students can choose between different majors. These two programs account for $86 \%$ of all bachelor's students. Figure 1 provides an 
overview of program structure of these two study programs. In the Business program students take sixteen and in the Business Economics program students eight program-specific compulsory courses at the beginning of their studies. After the compulsory course phase, students can choose elective courses and a major, which comprises four major-specific compulsory courses. Students are completely free to choose any major and there are no constraints on major choice in terms of grade requirements. For a more detailed description of the institutional environment, see also Feld and Zölitz (2017) and Feld, Salamanca and Hamermesh (2016).

Figure 1: Bachelor Program Structure

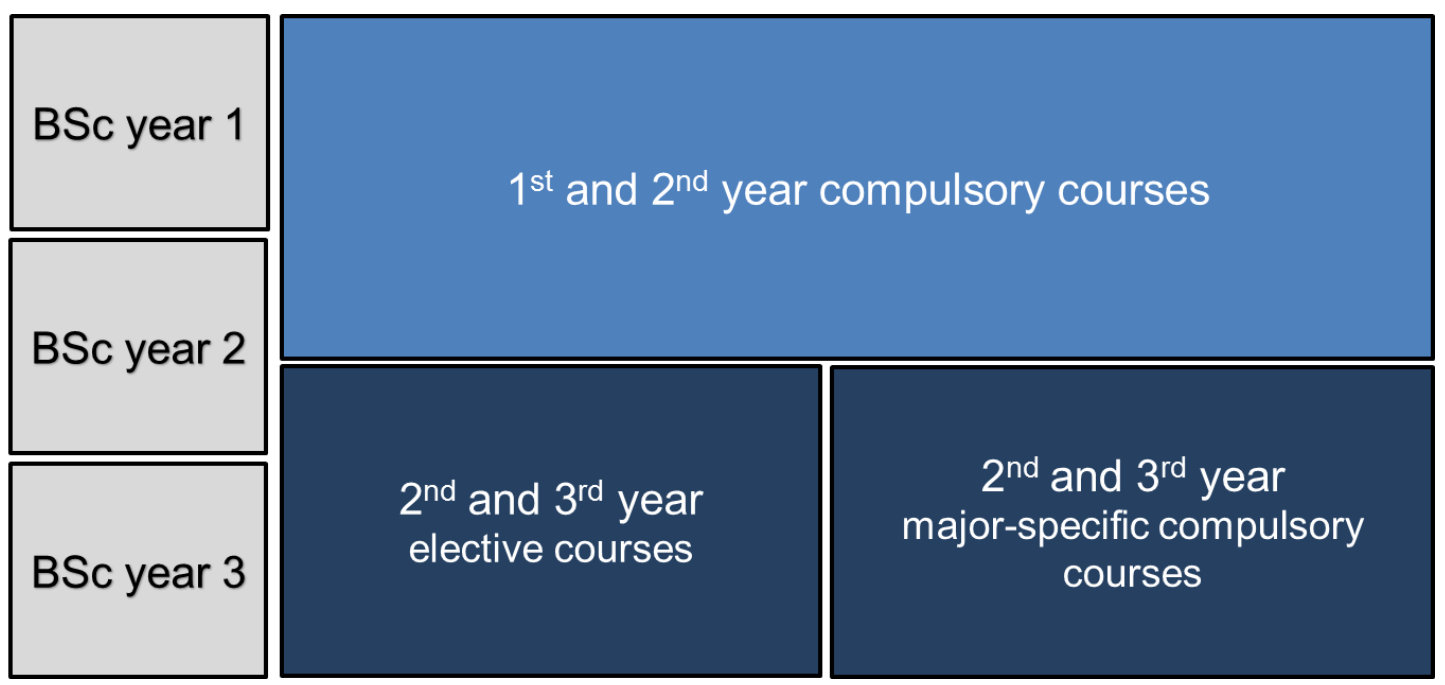

NOTE.-The figure shows the timing of compulsory courses, elective course and major-specific compulsory courses of the Business and Business Economics programs.

Each course comprises multiple sections of up to sixteen students, which are the peer group upon which we focus in this paper. Within their section, students typically meet peers for two weekly two-hour tutorial sessions. Students spend on about two-thirds of their contact hours in these tutorials where they intensively interact with fellow students. For each course students take student face a new group of section peers. In these tutorials, students solve problems and discuss the course material. These discussions typically follow the discussionbased approach, which involves students generating questions about a topic at the end of a session, trying to answer these questions in self-study and then discussing their findings with 
their peers in the next session. Attendance in tutorials is mandatory, and switching between sections is not allowed. Besides tutorials, a typical course has two-hour lectures weekly or fortnightly, which are followed by all students in the course.

Students are randomly assigned to sections and thus to section peers. The section assignment is undertaken with a scheduling software by the business school's scheduling department. From the academic year 2010/11, the business school additionally stratifies section assignment by student nationality to encourage a mixing of Dutch (38 percent of estimation sample) and German students (50 percent). ${ }^{7}$ After the initial assignment, schedulers manually switch students between sections to resolve any scheduling conflicts, which occur for about 5 percent of students. ${ }^{8}$ In our analysis, we consider potential non-random assignment due to scheduling conflicts by including fixed effects for the other courses that the students take at the same time. Schedulers do not consider the student composition when assigning instructors to sections, which makes the peer composition unrelated to instructor characteristics. We have excluded the few cases in which course coordinators or other staff influenced the section assignment (see Appendix A1 for more detailed description of the sample restrictions). For our estimation sample, neither teachers, students nor course coordinators influence the section assignment.

\footnotetext{
${ }^{7}$ The stratification is implemented as follows: the scheduler first selects all German students (who are not ordered by any observable characteristic) and then uses the option "Allocate Students set SPREAD," which assigns an equal number of German students to all sections. Subsequently, the scheduler repeats this process with the Dutch students and finally distributes the students of all other nationalities to the remaining spots. Until the academic year 2012/13, about ten percent of the slots in each section were initially left empty and were filled with students who register late. This procedure balances the number of late registration students over the sections. Since 2013/14, the business school has not admitted students to courses after the registration deadline.

${ }^{8}$ Compulsory courses are generally scheduled on different days to prevent scheduling conflicts. There are four reasons for students' scheduling conflicts: (1) the student is scheduled to take an elective course at the same time; (2) The student is also working as a student instructor and needs to be in class at the same time; (3) The student takes a language course at the same time. (4) Or the student indicated non-availability for evening education. By default, all students are recorded as available for evening sessions. Students can opt out of this by indicating this in an online form. Evening sessions are scheduled from 6 p.m. to 8 p.m., and about three percent of all sessions are scheduled for this time slot. We have excluded evening sessions from our estimation sample.
} 


\subsection{Descriptive Statistics and Randomization Check}

In this paper, we use data for six academic years between 2009/2010 and 2014/2015. In order to observe students' compulsory course peers and their major choices, we restrict our estimation sample to students who we observe in their first and last year of their bachelor's program. This implies we can follow four complete bachelor's student cohorts. Table 1 shows some descriptive statistics of our estimation sample at the student level (Panel A), studentcourse level (Panel B) and section level (Panel C). Overall, we observe 3,610 students. The sample contains 29,291 student course registrations. Out of the registered students, 992 (3.3 percent) dropped out of the course during the term period, which leaves us with 28,299 course grades.

Table 1: Descriptive Statistics

\begin{tabular}{|c|c|c|c|c|c|}
\hline Panel A: & (1) & (2) & (3) & (4) & (5) \\
\hline Student Level Characteristics & $\mathrm{N}$ & Mean & $\mathrm{Sd}$ & Min & $\operatorname{Max}$ \\
\hline Female & 3,610 & 0.388 & 0.487 & 0 & 1 \\
\hline Dutch & 3,610 & 0.256 & 0.436 & 0 & 1 \\
\hline German & 3,610 & 0.579 & 0.494 & 0 & 1 \\
\hline Age & 3,609 & 19.63 & 1.637 & 16.19 & 31.21 \\
\hline GPA & 3,030 & 7.027 & 1.190 & 1 & 10 \\
\hline Bachelor student & 3,610 & 1 & 0 & 1 & 1 \\
\hline BA Business & 3,610 & 0.560 & 0.496 & 0 & 1 \\
\hline BA Business Economics & 3,610 & 0.436 & 0.496 & 0 & 1 \\
\hline Courses taken & 3,610 & 16.64 & 7.300 & 1 & 39 \\
\hline Panel B: & (1) & (2) & (3) & (4) & (5) \\
\hline Student-course Level Characteristics & $\mathrm{N}$ & Mean & $\mathrm{Sd}$ & Min & Max \\
\hline Course dropout & 29,211 & 0.0338 & 0.181 & 0 & 1 \\
\hline Course grade & 28,223 & 6.583 & 1.714 & 1 & 10 \\
\hline Passed course & 28,223 & 0.804 & 0.397 & 0 & 1 \\
\hline Panel C: & (1) & (2) & (3) & (4) & (5) \\
\hline Section Level Characteristics & $\mathrm{N}$ & Mean & $\mathrm{Sd}$ & Min & $\operatorname{Max}$ \\
\hline Number of students in section & 2,559 & 13.71 & 1.300 & 3 & 16 \\
\hline Proportion female peers & 2,559 & 0.381 & 0.142 & 0 & 0.929 \\
\hline
\end{tabular}

NOTE.- This table is based on our estimation sample. 'Sd' refers to the standard deviation of the respective variable. 
Our explanatory variable of interest is the proportion of female section peers in compulsory courses. Thirty-nine percent of students, and thus peers, are female. Figure 2 shows the variation in proportion women we observe in the data. The solid line shows the proportion of women across all sections and the dashed line shows the mean proportion of women students had across all of their compulsory course sections. The relatively small section size and the random assignment lead to a relatively wide range of support that we can exploit.

\section{Figure 2: Proportion of Women in Section}

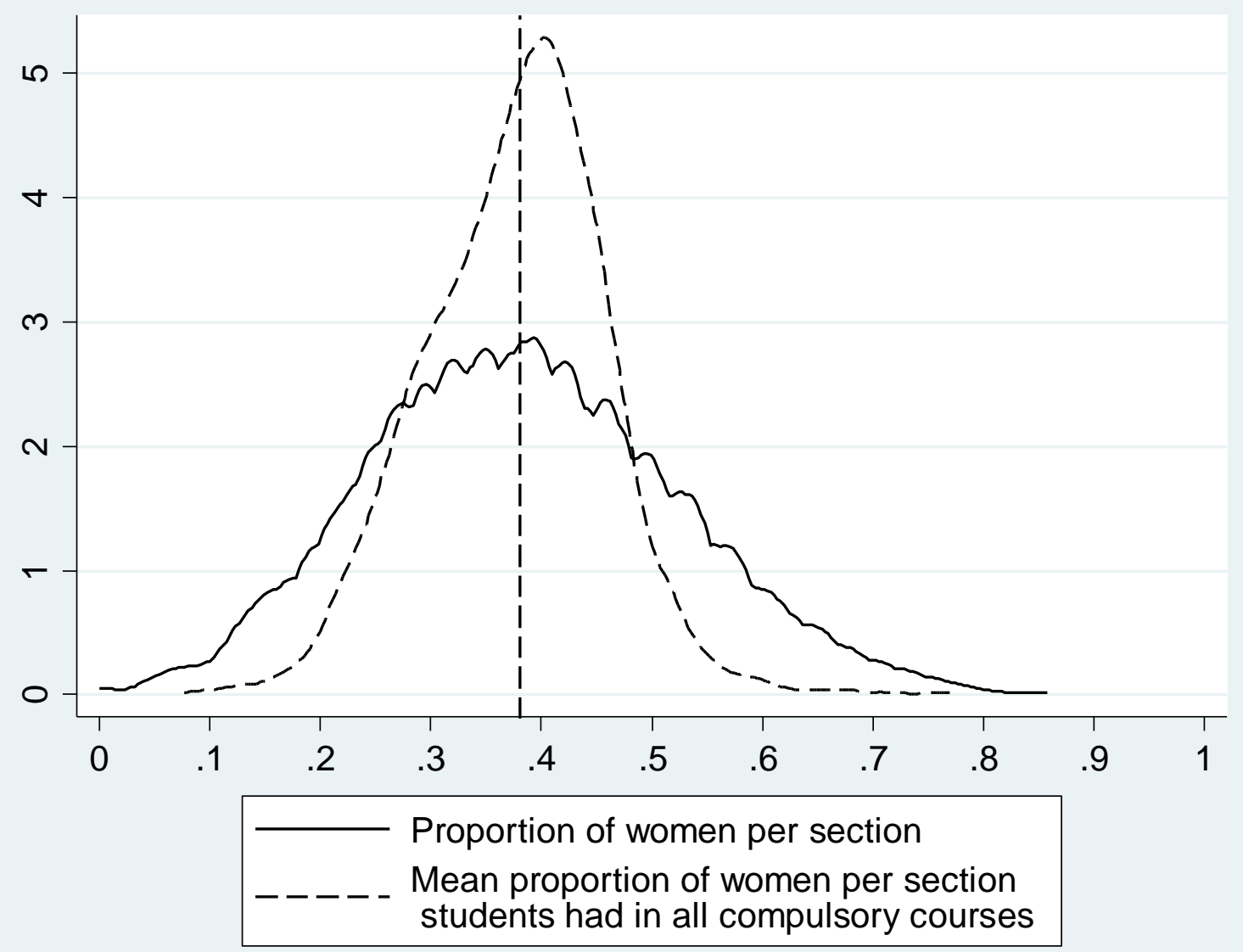

NOTE.-The figure is based on our estimation sample. 
Using data from the same environment, we have shown that section assignment has the properties that one would expect under random assignment (Feld and Zölitz, 2017). To confirm this result with respect to the peer gender composition, we test how the proportion of female peers relates to student gender and grade point average (GPA). This randomization check closely follows Guryan, Kroft and Notowidigdo (2009) and controls for the course level leaveout mean to account for the mechanical relationship between own gender and peer the proportion of female peers in Column (1) and (2). Table 2 shows that the proportion of female section peers is not systematically related to students' own gender or GPA for the sample of first and second year compulsory courses, which confirms that the section assignment is random. ${ }^{9}$

Table 2: Test for Random Assignment

\begin{tabular}{lcccc}
\hline Dependent Variable: & $\begin{array}{c}(1) \\
\text { Proportion } \\
\text { Female Peers }\end{array}$ & $\begin{array}{c}(2) \\
\text { Proportion } \\
\text { Female Peers }\end{array}$ & $\begin{array}{c}(3) \\
\text { Proportion } \\
\text { Female Peers }\end{array}$ & $\begin{array}{c}(4) \\
\text { Proportion } \\
\text { Female Peers }\end{array}$ \\
\hline Female & & & & \\
& -0.0027 & -0.0028 & & \\
Std. GPA & $(0.003)$ & $(0.003)$ & & 0.0015 \\
& & & $(0.001)$ & $(0.001)$ \\
Observations & & & & 29,211 \\
R-squared & & & 29,211 & 0.161 \\
Course x Year FE & 29,211 & 29,211 & 0.152 & YES \\
Parallel Course FE & 0.153 & 0.162 & YES & YES \\
Controlling for Course-Level Leave-out-Mean & YES & YES & NO & YES \\
\hline
\end{tabular}

NOTE.- The dependent variable in all columns is the proportion of female section peers. Following the Guryan, Kroft and Notowidigdo (2009) correction method, we control for the course-level leave-out-mean in Column (1) and (2). Robust standard errors using two-way clustering at the student and section level are in parentheses. * $\mathrm{p}<0.1, * * \mathrm{p}<0.05, * * * \mathrm{p}<0.01$.

\footnotetext{
${ }^{9}$ See Table A1 and Figure A1 in the appendix for an alternative and more flexible randomization check. In this randomization check, we regress pre-treatment student characteristics on section dummies and scheduling controls for each course separately. We then perform F-tests for joint significance of the section dummies and show that the p-values of these F-tests for all courses in our sample have the properties that we would expect under random assignment: they are uniformly distributed with a mean close to 0.5 .
} 


\subsection{Gender Differences in Major Choice}

Table 3 provides an overview of the eight different majors that students can choose from, ordered by the proportion of women per major, which ranges from 22 percent in Finance to 60 percent in Marketing. Interestingly, differences in major choices by gender mimic the occupational segregation observed in the labor market in two important dimensions. First, in line with women's underrepresentation in STEM occupations, majors that are more popular among women have a lower proportion of mathematical compulsory courses (Column 3). ${ }^{10}$ Second, majors more popular with women are associated with lower earnings for both women and men (Columns 7 and 8). The proportion of women is also negatively correlated with average first year GPA of women $(\rho=-0.55)$ and men $(\rho=-0.49)$ at the major level. This shows that despite the fact that women have higher average GPAs, majors with more women attract, on average, academically weaker students.

Table 3: Gender-Based Sorting into Majors

\begin{tabular}{|c|c|c|c|c|c|c|c|}
\hline \multirow{3}{*}{ Major } & \multirow{3}{*}{$\begin{array}{l}\text { Percent } \\
\text { Female }\end{array}$} & \multirow{3}{*}{$\begin{array}{c}\text { (2) } \\
\text { Major } \\
\text { Classification }\end{array}$} & \multirow{3}{*}{$\begin{array}{c}(3) \\
\text { Percent } \\
\text { Compulsory } \\
\text { Mathematical } \\
\text { Courses in } \\
\text { Major } \\
\end{array}$} & (4) & (5) & \multirow{2}{*}{\multicolumn{2}{|c|}{$\begin{array}{c}(6) \\
\text { Mean Annual Earnings } \\
\text { in Thousand } €\end{array}$}} \\
\hline & & & & \multicolumn{2}{|c|}{ First Year GPA } & & \\
\hline & & & & (Female) & (Male) & (Female) & (Male) \\
\hline Finance & 21.50 & Male-dominated & 50 & 7.29 & 7.15 & 55.86 & 58.33 \\
\hline IT Management & 30.43 & Male-dominated & 50 & 6.78 & 6.50 & 43.63 & 43.31 \\
\hline Strategy & 35.64 & Balanced & 0 & 6.94 & 6.52 & 43.58 & 47.87 \\
\hline Economics & 37.76 & Balanced & 50 & 7.10 & 6.96 & 40.31 & 43.20 \\
\hline Accounting & 39.09 & Balanced & 0 & 7.29 & 7.20 & 39.04 & 46.98 \\
\hline Supply Chain Mgmt & 48.78 & Balanced & 25 & 6.93 & 6.55 & 38.72 & 40.77 \\
\hline Organization & 59.51 & Female-dominated & 0 & 6.86 & 6.52 & 34.24 & 46.72 \\
\hline Marketing & 60.34 & Female-dominated & 0 & 6.81 & 6.61 & 40.14 & 45.72 \\
\hline
\end{tabular}

NOTE.-We define male-dominated and female-dominated majors as majors that deviate by more than 10 percentage points from the average proportion of women by major groups. Data on annual earnings is taken from the 2016 graduate survey. $\mathrm{N}=1,713$.

\footnotetext{
${ }^{10}$ We categorize courses as mathematical if at least one of the following words appeared in the course description: "math, mathematics, mathematical, statistics, statistical, theory focused." Using this definition, we categorized 33 percent of the courses as "mathematical".
} 
For our empirical analysis, we classify majors as being female- or male-dominated if the proportion of women deviates by more than 10 percentage points from the share of women in our estimation sample. Specifically, we classify Finance and IT Management as maledominated, and Organization and Marketing as female-dominated.

\section{Empirical Strategy}

Our goal is to estimate the effect of peer gender in first and second year compulsory courses on students' subsequent major choices and labor market outcomes. Equation (1) shows our main empirical model:

$$
Y_{i t+}=\alpha_{1} F_{i} \times F P_{i s c t}+\alpha_{2} M_{i} \times F P_{i s c t}+X_{i c t} \gamma^{\prime}+u_{i s c t},
$$

where $Y_{i t+}$ is the outcome of interest (major choice, course choice or labor market outcome such as earnings) of student $i$ at time $t+>t$, after having taken the compulsory course. $F_{i} \times F P_{i s c t}$ is a female dummy variable interacted with the proportion of female peers in section $s$ of compulsory course $c$ at time $t$, and $M_{i} \times F P_{i s c t}$ is a male dummy interacted with the proportion of female peers. The parameters of interest are $\alpha_{1}$ and $\alpha_{2}$, which show the causal effect of increasing the proportion of female peers on the outcome of interest for women and men respectively. ${ }^{11} X_{i c t}$ is a vector of control variables that includes course-year fixed effects and parallel course fixed effects, which are fixed effects for the other course the students take in the same period. We include parallel course fixed effects to account for potential non-random assignment due to scheduling conflicts throughout. We control for students' own gender and,

\footnotetext{
${ }^{11}$ We have shown in Feld and Zölitz (2017) that classical measurement error in the peer variable of interest can lead to substantial overestimation of peer effects when peer group assignment is non-random. When peer group assignment is random, as is the case in our setting, classical measurement error will attenuate peer effects estimates, i.e. bias them towards zero. As peer gender is measured with very little error, attenuation bias in OLS estimates of $\alpha_{1}$ and $\alpha_{2}$ will not be a concern.
} 
in order to increase the precision of our estimates, $X$ also includes indicators for the students' nationality and their GPA at the start of the course. We cluster standard errors using two-way clustering at the student and section level. ${ }^{12}$

\section{Results}

\subsection{Peer Effects on Major Choice}

Table 4 shows estimates of how the peer composition affects students' choice of maledominated and female-dominated majors. Women who are randomly assigned to sections with more female peers become more likely to choose female-dominated majors and less likely to choose male-dominated majors (Columns 1 and 2). In order to gain an appreciation of the magnitude of these effects, imagine that we replaced three men with women in a section of sixteen students (fifteen peers). Our point estimates suggest that such a 20-percentage-point increase in female peers would reduce the probability of a woman choosing to major in Finance or IT Management by 1.6 percentage points (16 percent) and increase her probability of majoring in Marketing or Organization by 2 percentage points (4 percent). These effects are economically significant. Men respond in the opposite way and become less likely to choose a female-dominated major and more likely to choose a male-dominated major when they had more female peers. In order to test whether these results are sensitive to the definition of maleand female-dominated majors, we also estimate a model with the proportion of women in the chosen major as dependent variable. The results in this specification are qualitatively similar (Column 3). ${ }^{13}$

\footnotetext{
${ }^{12}$ For almost all regression coefficients, we obtain smaller or same-sized standard errors when clustering at the section level or at the student level.

${ }^{13}$ One might be worried that peer gender affects student dropout rate which would complicated our interpretation of the estimates on major choice and course choice. In order to address this concern, we test whether peer gender is significantly related to student dropout. Table A2 in the appendix shows that this is not the case.
} 
Table 4: The Impact of Gender Composition on Course and Major Choices

\begin{tabular}{|c|c|c|c|c|c|}
\hline Dependent Variable: & $\begin{array}{c}(1) \\
\text { Male- } \\
\text { dominated } \\
\text { Major }\end{array}$ & $\begin{array}{c}(2) \\
\text { Female- } \\
\text { dominated } \\
\text { Major }\end{array}$ & $\begin{array}{c}(3) \\
\text { Proportion } \\
\text { Women in } \\
\text { Major }\end{array}$ & $\begin{array}{c}\text { (4) } \\
\text { Any } \\
\text { Mathematical } \\
\text { Elective }\end{array}$ & $\begin{array}{c}(5) \\
\text { Fraction } \\
\text { Mathematical } \\
\text { Electives }\end{array}$ \\
\hline Female * Proportion Female Peers & $\begin{array}{c}-0.0812 * * * \\
(0.028)\end{array}$ & $\begin{array}{c}0.1007 * * * \\
(0.038)\end{array}$ & $\begin{array}{c}0.0296 * * * \\
(0.010)\end{array}$ & $\begin{array}{c}-0.1197 * * * \\
(0.038)\end{array}$ & $\begin{array}{c}-0.0399 * * \\
(0.018)\end{array}$ \\
\hline Male * Proportion Female Peers & $\begin{array}{c}0.0639 * * \\
(0.029)\end{array}$ & $\begin{array}{c}-0.0988 * * * \\
(0.027)\end{array}$ & $\begin{array}{c}-0.0297 * * * \\
(0.008)\end{array}$ & $\begin{array}{l}0.0463 \\
(0.028)\end{array}$ & $\begin{array}{l}0.0113 \\
(0.015)\end{array}$ \\
\hline Female & $\begin{array}{c}-0.1337 * * * \\
(0.019)\end{array}$ & $\begin{array}{c}0.1298 * * * \\
(0.022)\end{array}$ & $\begin{array}{c}0.0458 * * * \\
(0.006)\end{array}$ & $\begin{array}{c}-0.0654 * * * \\
(0.021)\end{array}$ & $\begin{array}{c}-0.0330^{* * *} \\
(0.012)\end{array}$ \\
\hline Observations & 29,211 & 29,211 & 29,211 & 30,590 & 30,590 \\
\hline R-squared & 0.125 & 0.235 & 0.167 & 0.216 & 0.248 \\
\hline Mean Dependent Variable & .1999 & .3336 & .3975 & .5977 & .2271 \\
\hline Mean Dependent Variable Women & .0977 & .4797 & .4415 & .4963 & .1885 \\
\hline Mean Dependent Variable Men & .2687 & .2352 & .3679 & .6633 & .2521 \\
\hline $\begin{array}{l}\text { p-values of Test for Gender Equality } \\
\text { of Proportion Female Peers }\end{array}$ & .0008 & .0001 & $<.0001$ & 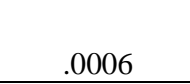 & .045 \\
\hline
\end{tabular}

NOTE. - The dependent variables in Columns (1) and (2) are dummy variables which are equal to 1 if students choose a male-dominated major and female-dominated major, respectively. The dependent variable in Column (3) is the proportion of women in the chosen major. The dependent variable in Column (4) is a dummy variable which is equal to 1 if the student chose at least one mathematical course. The dependent variable in Column (5) is the fraction of chosen courses that are mathematical. Overall, we observe the course choices for 3,295 students and the major choices for 3,083 students. All columns are estimated with ordinary least squares regressions that include course-times-year fixed effects, parallel course fixed effects, female, Std. GPA, Dutch and German. Robust standard errors using two-way clustering at the student and section level are in parentheses. $*$ p $<0.1, * *$ $\mathrm{p}<0.05, * * * \mathrm{p}<0.01$.

In addition to looking at student major choices, we can also test whether the choice of students' elective courses is affected. ${ }^{14}$ Table 4 shows estimates of the effect of peer gender on the choice of any mathematical course (Column 4) and on the proportion of mathematical courses chosen (Column 5). On both of these margins, we observe that women become less likely to choose mathematical courses if they are randomly assigned to more female peers. Our point estimates suggest that increasing the proportion of female peers by 10 percentage points reduces the probability of choosing a mathematical course by about 1.2 percentage points $(2.4$

\footnotetext{
${ }^{14}$ When estimating the effect on course choice, we limit our sample to courses that students could choose either as a free elective or as major-specific compulsory course.
} 
percent). ${ }^{15}$ Taken together, our results show that an increase in the proportion of female peers leads to an increase in gender segregation in specialization choices. Having more female peers causes men and women to choose courses and majors that are more popular with their own gender.

Our results are largely consistent with a study by Hill (2017), who finds suggestive evidence that women in US colleges are less likely to graduate in STEM majors when they are in a cohort with more female peers. However, these results only hold in specifications with time trends. Two other studies have explored the effect of high school peer gender on university major choice. In line with our findings, Brenøe and Zölitz (2017) show that female students with more female peers in Danish high school are less likely to complete a STEM degree and more likely to complete a health degree. Contrary to our results, Anelli and Peri (2017) show that male students in Italian high schools with less than 20 percent female peers become more likely to choose a male-dominated major. The differences between studies may be a result of the different study environment and definitions of peer groups (high school cohort, university cohort, university section) and therefore different channels through which peer effects operate. We will return to the importance of different underlying mechanisms in Section 5. We next turn to the question of whether peers affect students' labor market outcomes.

\subsection{Peer Effects on Labor Market Outcomes}

In order to test whether peer gender affects labor market outcomes, we use data from the 2016 graduate survey that we sent to students who graduated between September 2010 and

\footnotetext{
15 In addition to the linear-in-shares models shown in Table 4, we have also estimated non-linear peer effects using five bins for the proportion of female peers. In this exercise, we find fairly linear effects. Figure A2 in the appendix reveals little concavity and suggests that peer effects are fairly linear over the range of support that we have in the data.
} 
September $2015 .{ }^{16}$ The survey includes a number of questions which allow us to obtain a detailed picture of graduates' occupational situation 1 to 5 years after graduation. ${ }^{17}$

Table 5 shows the estimated effect of peer gender on a number of key labor market outcomes. Overall, university peers affect women's but not men's labor market outcomes. These gender differences are somewhat surprising although not unheard of, given that other studies find effects limited to one gender (e.g. Anelli and Peri, 2017; Brenøe and Zölitz, 2017).

Table 5 shows results from regressions of peer gender on students' labor market outcomes. Having more female peers has no significant impact on earnings in the first job after graduation (Column 1) but a negative impact on current total earnings (Column 2) and a marginally significant negative impact on hourly earnings (Column 3). These findings suggest that having more female peers causes women to choose jobs which have lower earnings growth. This is indeed the case as, women who are exposed to 10 percentage points more female peers end up in jobs where their wage has grown 0.3 percentage points less after graduation (Column 4). We further find suggestive evidence that women who had more female peers work fewer hours per week (Column 5). The effects on working hours are economically significant. A 10-percentage-point increase in the proportion of female peers reduces weekly working hours by 20 minutes. Women who had more female peers also report marginally significantly higher job satisfaction (Column 6) and a more positive social impact of their job

\footnotetext{
${ }^{16}$ We designed and conducted the survey in cooperation with the business school's alumni office, which provided us with contact details for 75 percent of bachelor's students in our estimation sample. We first contacted the graduates via email and provided them with a link to the online survey. We then hired a team of current students from the business school who called the graduates who did not respond to the online survey to conduct the survey over the phone. Out of the contacted graduates, 38 percent responded to either the email or phone survey, which means that we have labor market outcome information for 1,618 students, about 30 percent of our estimation sample. We tested whether the gender composition of peers affects the probability that they participate in our labor market survey. Table A3 shows that respondents differ from non-respondents in a number of observable characteristics. Respondents have higher GPAs, are marginally older and somewhat less likely to be Dutch and more likely to be German. We do not find that students' major choice is related to their response probability. More importantly, Table A2 shows that proportion of female peers is unrelated to probability of responding to the labor market survey (Column 3) and the probability of the respondents report to be working (Column 2).

${ }^{17}$ Table A4 in the Appendix provides summary statistics for the labor market variables. Table A5 in the Appendix shows the original survey questions, the survey answer options and the definition of our dependent variables.
} 
(Column 7), although the latter effect is not statistically significant. We further test whether

peer gender affects the type of job graduates choose. These estimates are generally less

conclusive due to lack of precision, but the point estimates suggest that women with more

female peers are less likely to end up in Finance and IT jobs and more likely to work part time.

For brevity, we report these estimates in Table A6 in the Appendix.

Table 5: The Impact of Gender Composition on Labor Market Outcomes

\begin{tabular}{|c|c|c|c|c|c|c|c|}
\hline Dependent Variable: & $\begin{array}{c}\text { (1) } \\
\text { Log } \\
\text { First } \\
\text { Earnings } \\
\text { per Year }\end{array}$ & $\begin{array}{c}\text { (2) } \\
\text { Log } \\
\text { Current } \\
\text { Earnings } \\
\text { per Year }\end{array}$ & $\begin{array}{c}\text { (3) } \\
\text { Log } \\
\text { Hourly } \\
\text { Wage }\end{array}$ & $\begin{array}{c}\text { (4) } \\
\text { Wage } \\
\text { Growth }\end{array}$ & $\begin{array}{c}\text { (5) } \\
\text { Working } \\
\text { Hours }\end{array}$ & $\begin{array}{c}(6) \\
\text { Job } \\
\text { satisfaction }\end{array}$ & $\begin{array}{c}(7) \\
\text { Subjective } \\
\text { Social } \\
\text { Impact }\end{array}$ \\
\hline Female * Proportion Female Peers & $\begin{array}{l}0.0704 \\
(0.130)\end{array}$ & $\begin{array}{c}-0.5224 * * \\
(0.258)\end{array}$ & $\begin{array}{c}-0.4280 * \\
(0.238)\end{array}$ & $\begin{array}{c}-0.0338 * * * \\
(0.012)\end{array}$ & $\begin{array}{c}-3.2558 * \\
(1.703)\end{array}$ & $\begin{array}{c}0.3504 * \\
(0.212)\end{array}$ & $\begin{array}{l}0.3826 \\
(0.245)\end{array}$ \\
\hline Male * Proportion Female Peers & $\begin{array}{l}0.0776 \\
(0.111)\end{array}$ & $\begin{array}{l}-0.0261 \\
(0.202)\end{array}$ & $\begin{array}{c}-0.0369 \\
(0.202)\end{array}$ & $\begin{array}{l}0.0110 \\
(0.009)\end{array}$ & $\begin{array}{l}1.0058 \\
(1.394)\end{array}$ & $\begin{array}{l}0.0900 \\
(0.201)\end{array}$ & $\begin{array}{l}-0.0592 \\
(0.217)\end{array}$ \\
\hline Female & $\begin{array}{r}-0.1087 \\
(0.086)\end{array}$ & $\begin{array}{l}-0.1053 \\
(0.128)\end{array}$ & $\begin{array}{c}-0.0711 \\
(0.125)\end{array}$ & $\begin{array}{l}0.0081 \\
(0.008)\end{array}$ & $\begin{array}{c}-2.4958^{* *} \\
(1.049)\end{array}$ & $\begin{array}{l}-0.2582 \\
(0.158)\end{array}$ & $\begin{array}{l}0.0426 \\
(0.181)\end{array}$ \\
\hline Observations & 9,523 & 9,263 & 9,238 & 8,916 & 9,576 & 9,652 & 9,668 \\
\hline R-squared & 0.104 & 0.104 & 0.071 & 0.038 & 0.165 & 0.043 & 0.695 \\
\hline Mean Dependent Variable & 10.3606 & 10.4993 & 2.7047 & .0171 & 48.4168 & 81.407 & 6.3059 \\
\hline Mean Dep. Var. Women & 10.2873 & 10.3183 & 2.5734 & .012 & 45.7415 & 8.0646 & 6.6364 \\
\hline $\begin{array}{l}\text { Mean Dep. Var. Men } \\
\text { p-value of Test for Gender }\end{array}$ & 10.4062 & 10.6138 & 2.788 & .0204 & 50.144 & 81.903 & 6.0899 \\
\hline $\begin{array}{l}\text { Equality of Proportion Female } \\
\text { Peers }\end{array}$ & .9664 & .1369 & .2157 & .0038 & .0692 & .419 & .2175 \\
\hline
\end{tabular}

NOTE.- The dependent variable in Column (1) is equal to the first log of self-reported yearly gross earnings after graduation including bonuses and holiday allowances. The dependent variable in Column (2) is equal to the current $\log$ of self-reported yearly gross earnings including bonuses and holiday allowances. The dependent variable in Column (3) is current log hourly wage calculated based on information on earnings and working hours. The dependent variable in Column (4) is wage growth calculated as the difference between current and first earnings divided by first earnings. The dependent variables in Column (5) is self-reported weekly working hours including overtime. The dependent variable in Column (6) is self-reported job satisfaction on a 1-10 scale. The dependent variable in Column (7) is self-assessed social impact of the graduate's job measured on a -5 to +5 scale that includes a zero to indicate neutral social impact. All Columns are estimated with ordinary least squares regressions that include course-times-year fixed effects, parallel course fixed effects, female, Std. GPA, Dutch and German. All Columns include a dummy for whether the survey data was collected by phone interviews (as opposed to email). Differences in the number of observations are due to students not answering specific questions. Robust standard errors using two-way clustering at the student and section level are in parentheses. $* \mathrm{p}<0.1, * *$ $\mathrm{p}<0.05$, *** $\mathrm{p}<0.01$. 
Overall, our findings suggest that women sort into different into jobs with lower earnings growth where they work fewer hours and are more satisfied when they had more female peers. These findings relate to studies on gender differences in preferences for workplace attributes. Wiswall and Zafar (2017) use hypothetical choice experiments to show that women have a higher willingness to give up earnings in favor of jobs where they enjoy greater work flexibility and job stability. Lordan and Pischke (2016) show that women in occupations with a higher share of women report higher job satisfaction and argue that women in contrast to men may care more about job content. Bertrand, Goldin and Katz (2010) show that although men and women have very similar earnings at the start of their careers, their earnings diverge later, which can be partly explained by differences in working hours. ${ }^{18}$ Our results suggest that having more female peers may have increased gender differences in preferences for workplace attributes.

\section{Mechanisms}

Two mechanisms that could drive our results are the effects of peer gender on subject ability and on subject preferences. We understand subject ability broadly as all factors that help students do well in a major, including subject-specific knowledge. In order to test whether peers' influence on students' subject ability drives our results on major choice, we look at how peer gender affects students' grades in mathematical compared to non-mathematical compulsory courses. Performing better in mathematical courses compared to nonmathematical courses, may make students more likely to choose a more mathematical, male-

\footnotetext{
${ }^{18}$ Bertrand et al. (2010) study how career dynamics differ by gender. Although male and female MBAs have nearly identical income at the start of their careers, their earnings soon diverge. Men's annual earnings advantage reaches almost $60 \log$ points at ten to sixteen years after MBA completion. The authors identify three main reasons for the large and rising gender gap in earnings: differences in training prior to MBA graduation, differences in career interruptions and differences in weekly working hours.
} 
dominated major. In order to test whether peers affect subject preferences, we investigate whether peer gender affects students' evaluations of the course and the group functioning differently in mathematical compared to non-mathematical courses. Empirically, we test both mechanisms by adding interaction terms of our peer variables of interest with a dummy variable for mathematical courses to our main model. We discuss other potential mechanisms in Section 5.3 .

\subsection{Mechanism (1) - Effect on Subject Ability}

Many studies have shown that having more female peers raises students' performance (e.g. Hill, 2015, 2017; Hoxby, 2000; Lavy and Schlosser, 2011; Whitmore, 2005). Columns (1) and (2) of Table 6 show how peer gender affects students' grades in compulsory courses and how this effect differs between mathematical and non-mathematical courses. ${ }^{19}$ Confirming previous studies, we find that, on average, women marginally benefit from having more female peers, while men's grades are hardly affected. However, these average effects hide important heterogeneity: women only benefit from female peers in mathematical courses, while the opposite holds for men. An increase in female peers by 10 percentage points increases women's grades in non-mathematical courses by 1.2 percent of a standard deviation, while not affecting their grades in mathematical courses. For men, a 10-percentage-point increase in female peers increases their grades by 1.3 percent of a standard deviation in mathematical courses, while not affecting their grades in non-mathematical courses.

These heterogeneous effects are consistent with the idea that the effect of peer gender on subject-specific ability drive our results on major choice. Women with more female peers receive higher grades in non-mathematical courses, which they may interpret as feedback that

\footnotetext{
${ }^{19}$ See summary statistics of student grades and student course evaluations in Table A7 in the appendix.
} 
they are better prepared for a less mathematical, female-dominated majors. The opposite holds for men, who may interpret their higher grades in mathematical courses as evidence that they are better prepared for more mathematical, male-dominated majors. We return to the question of why we observe these asymmetries by course type in the mechanisms discussion section.

Table 6: Mechanisms: Student Achievement, Effort, Overall Evaluation and Group Functioning

\begin{tabular}{|c|c|c|c|c|c|c|}
\hline Dependent Variable: & $\begin{array}{c}(1) \\
\text { Std. } \\
\text { Grade }\end{array}$ & $\begin{array}{c}(2) \\
\text { Std. } \\
\text { Grade }\end{array}$ & $\begin{array}{c}(3) \\
\text { Std. } \\
\text { Overall } \\
\text { Evaluation }\end{array}$ & $\begin{array}{c}\text { (4) } \\
\text { Std. } \\
\text { Overall } \\
\text { Evaluation } \\
\end{array}$ & $\begin{array}{l}\quad \text { (5) } \\
\text { Std. Group } \\
\text { Functioning }\end{array}$ & $\begin{array}{c}\text { (6) } \\
\text { Std. Group } \\
\text { Functioning }\end{array}$ \\
\hline Female * Proportion Female Peers & $\begin{array}{c}0.0804 * * \\
(0.041)\end{array}$ & $\begin{array}{c}0.1213 * * * \\
(0.045)\end{array}$ & $\begin{array}{l}0.0729 \\
(0.111)\end{array}$ & $\begin{array}{l}0.2431^{*} \\
(0.128)\end{array}$ & $\begin{array}{l}0.1971 \\
(0.138)\end{array}$ & $\begin{array}{c}0.3672 * * \\
(0.146)\end{array}$ \\
\hline Male * Proportion Female Peers & $\begin{array}{l}0.0385 \\
(0.037)\end{array}$ & $\begin{array}{r}-0.0047 \\
(0.044)\end{array}$ & $\begin{array}{l}0.1100 \\
(0.109)\end{array}$ & $\begin{array}{l}0.1559 \\
(0.130)\end{array}$ & $\begin{array}{r}-0.0858 \\
(0.117)\end{array}$ & $\begin{array}{l}0.0217 \\
(0.129)\end{array}$ \\
\hline $\begin{array}{l}\text { Female * Proportion Female Peers * } \\
\text { Math Course }\end{array}$ & & $\begin{array}{c}-0.1305 * * \\
(0.056)\end{array}$ & & $\begin{array}{l}-0.4910 * * * \\
(0.173)\end{array}$ & & $\begin{array}{c}-0.5539 * * \\
(0.236)\end{array}$ \\
\hline $\begin{array}{l}\text { Male * Proportion Female Peers * } \\
\text { Math Course }\end{array}$ & & $\begin{array}{c}0.1311^{* *} \\
(0.054)\end{array}$ & & $\begin{array}{l}-0.0803 \\
(0.168)\end{array}$ & & $\begin{array}{l}-0.3000 \\
(0.201)\end{array}$ \\
\hline Female & $\begin{array}{l}0.0011 \\
(0.024)\end{array}$ & $\begin{array}{l}0.0053 \\
(0.024)\end{array}$ & $\begin{array}{l}-0.0225 \\
(0.057)\end{array}$ & $\begin{array}{l}-0.0115 \\
(0.057)\end{array}$ & $\begin{array}{c}-0.1154 * \\
(0.066)\end{array}$ & $\begin{array}{r}-0.1084 \\
(0.066)\end{array}$ \\
\hline Observations & 36,549 & 36,549 & 11,077 & 11,077 & 10,220 & 10,220 \\
\hline R-squared & 0.520 & 0.521 & 0.177 & 0.179 & 0.103 & 0.104 \\
\hline Mean Dependent Variable & .0005 & .0005 & -.0573 & -.0573 & -.0591 & -.0591 \\
\hline Mean Dependent Variable Women & .0661 & .0661 & -.0909 & -.0909 & -.0594 & -.0594 \\
\hline $\begin{array}{l}\text { Mean Dependent Variable Men } \\
\text { p-values: Test of Gender Equality for }\end{array}$ & -.0427 & -.0427 & -.0303 & -.0303 & -.0588 & -.0588 \\
\hline $\begin{array}{l}\text { Proportion Female Peers } \\
\text { Proportion Female Peers * Math course }\end{array}$ & .4488 & $\begin{array}{c}.0246 \\
<.0001\end{array}$ & 0.7929 & $\begin{array}{l}.5466 \\
<.0001\end{array}$ & .0793 & $\begin{array}{l}.0338 \\
.0335\end{array}$ \\
\hline
\end{tabular}

NOTE.- The dependent variable in Columns (1) and (2) is standardized course grade. The dependent variable in Columns (3) and (4) is standardized overall course evaluation. The dependent variable in Columns (5) and (6) is standardized group functioning. "Group functioning" is measured using the standardized sum of standardized answers to the two questions: "My tutorial group has functioned well" and "Working in tutorial groups with my fellow-students helped me to better understand the subject matters of this course." Overall course quality is measured with the question: "Please give an overall grade for the quality of this course." All Columns are estimated with ordinary least squares regressions that include course-times-year fixed effects, parallel course fixed effects, female, Std. GPA, Dutch and German. Columns (2), (4) and (6) additionally control for the interaction between female and math course. Robust standard errors using two-way clustering at the student and section level are in parentheses. $* \mathrm{p}<0.1, * * \mathrm{p}<0.05, * * * \mathrm{p}<0.01$ 


\subsection{Mechanism (2) - Effect on Subject Preferences}

Previous research has shown that enjoyment of coursework is an important determinant of major choice and gender differences in major choice (Baker et al. 2017; Hastings el al. 2016; Zafar, 2013) and that female peers improve the classroom atmosphere (Figlio, 2007; Lavy and Schlosser, 2011; Oosterbeek and van Erwijk, 2014). Therefore, peer gender may affect major choice by affecting which courses students enjoy.

We use data from the course evaluation survey to investigate the effect of female peers on overall course satisfaction and perceived group functioning. ${ }^{20}$ We measure course satisfaction with the answer to the question "Please give an overall grade for the quality of this course." In order to facilitate the interpretation of the answers, we standardize the questionnaire response to have a mean of zero and standard deviation of one. In order to measure group functioning, we use the two following questions: (1) "My tutorial group has functioned well" and (2) "Working in tutorial groups with my fellow-students helped me to better understand the subject matters of this course." We combine both questions to a group functioning index by standardizing the answers to each question, calculating the average of the standardized values for each student and then standardizing the resulting variable again to have a mean of zero and standard deviation of one.

Columns (3) to (6) of Table 6 show estimates of how the gender composition affects students' evaluation of the overall course and the perceived group functioning for mathematical compared to non-mathematical courses. On average, women's and men's overall course evaluations are not significantly affected by the gender composition of peers. However, the effect of an increase in female peers for women significantly differs between mathematical and non-mathematical courses: having 10 percentage points more female peers reduces women's evaluation of mathematical courses by 2.5 percent of a standard deviation and increases their

\footnotetext{
${ }^{20}$ Evaluation survey response is unrelated to the proportion of female peers (see Table A2 in the appendix).
} 
evaluation of non-mathematical courses by 2.4 percent of a standard deviation. These estimated effects closely resemble the estimates on group functioning. Having more female peers leads women to evaluate the group functioning more negatively in mathematical courses and more positively in non-mathematical courses. These results suggest that having more female peers affects women's preferences for majoring in a less mathematical subject. Men's evaluations of the course and group functioning are overall less affected by peer gender, with no significant differences between mathematical and non-mathematical courses.

\subsection{Mechanism - Discussion}

We find suggestive evidence that peer effects on ability and preferences drive our results on major choice. Women who had by chance more female peers have reasons to believe that they would perform better in less mathematical subjects and would enjoy these subjects more. Men's grades benefit from female peers more in mathematical courses, which is also consistent with their higher likelihood of choosing a male-dominated major.

While these mechanisms are consistent with our results, it is unclear what causes this heterogeneity by gender and course type in the first place. For example, it may be the case that women benefit from more female peers in non-mathematical courses because these courses are more discussion based. A higher proportion of female peers in these courses may thus lead to the engagement of more women in discussions, which may help their understanding of the course material. This mechanism may be less important in mathematical courses, where more time is dedicated to solving problems on the whiteboard. By contrast, men may benefit from

more female peers in mathematical courses because they spend more time solving exercises on the whiteboard if women are generally less willing to present their work in front of their peers. 
Of course, there are other ways to explain our results. One potential mechanism is the social coordination of major choices, whereby students might either directly coordinate their major choices or find majors more attractive if more of their same (or opposite) gender peers plan to take them. We test this mechanism by investigating how the proportion women in a section affects the homogeneity of major choices among students in that section. We measure diversity in major choice with the Blau index, which is the inverse of the Herfindahl-Hirschman Index often used to measure market concentration. Our results show that sections with more women lead to more homogeneity among women's major choices, providing suggestive evidence that women coordinate their major with their female peers. We find no evidence of men's coordination of major choices. For brevity, we describe our estimation procedure and results more extensively in Appendix A2.

Finally, another prominent potential mechanism is a change in gender norms. For example, it could be the case that peers affect what students consider to be the appropriate gender norms, or they affect their salience (Akerlof and Kranton, 2000; 2002). A similar argument has been put forward to explain why girls are more likely to choose traditionally male subjects in single-sex schools: with no boys around, girls feel less compelled to 'act like a girl' and become more open to study what they want to study (Solnick, 1995; Thompson, 2003). However, it is unclear how this mechanism would translate into a coeducational setting where the gender composition changes at a very different margin. ${ }^{21}$ The importance of gender norms may increase with the number of same gender peers. For example, having more female peers in the classroom may provide women with more role models from which to learn or imitate gender norms. This mechanism is consistent with our results that women choose more female typical majors when they have more female peers. However, the importance of gender

\footnotetext{
${ }^{21}$ The impact of adding the first male student to an all-female class is likely to be quite different than adding an additional male student to a coeducational class. Relatedly, Lee et al. (2014) show that gender peer effects on performance differ between coeducational classes, single-sex classes and single-sex schools.
} 
norms may also decrease with the number of same gender peers. For example, having more female peers in the classroom may make gender differences less salient and reduce the importance of gender norms. Contrary to our findings, this mechanism would predict that women with more female peers choose less female typical majors. While we believe that gender norms are important in our context, it is unclear how norms change when the proportion of female peers changes. ${ }^{22}$

\section{Conclusion}

While gender differences in students' specialization choices in higher education are well documented, we know little about where they originate from. In this paper, we have shown that the gender composition of peers affects students' major choice and labor market outcomes. An increase in the proportion of female peers increases gender-based sorting into university majors. Women who had more female peers at the start of their university education become less likely to choose male-dominated majors like Finance or IT Management. By contrast, men who had more female peers become more likely to choose a male-dominated majors. We can attribute these peer effects on major choice in part to differences in gender peer effects in mathematical and non-mathematical courses: women who have more female peers fare relatively better in non-mathematical courses, while men benefit relatively more from female peers in mathematical courses. These experiences suggest that peers affect subject-specific ability and preference, which prompts students to believe that they are better prepared for a major popular with their own gender. The gender composition of peers has significant and

\footnotetext{
${ }^{22}$ A related mechanism that could explain our results has been put forward by Bursztyn, Fujiwara and Pallais (2017). They propose that women may avoid career-enhancing actions because these signal traits, like ambition, are undesirable in the marriage market. In line with this reasoning, a higher proportion of female peers may increase competition for men and thus may make women less likely to choose a competitive male-dominated major which signals 'undesirable' traits like ambitiousness. By contrast, one could argue that increased competition for men may make women more likely to choose a male-dominated major because such a major will lead to exposure to more potential mates.
} 
lasting effects on woman's but not men's labor market outcomes. Women who had more female peers end up in jobs where they work fewer hours and their wages grow more slowly, although they are also marginally more satisfied.

Our results have implications for the persistence of the gender wage gap. Over recent decades, female college enrolment has substantially increased, which has led to a narrowing of the gender wage gap. However, this increase in college enrolment has also dramatically changed the social environment at university. The average student in a today's university is surrounded by many more female peers than a student in the 1950s. Our findings could potentially suggest that this substantial change in social environment may affect students' specialization choices in university. While also many other factors affecting gender equality have changed over this time period, the increase in female students in university might partly explain why occupational gender segregation of university graduates persists in today's labor market.

\section{REFERENCES}

Altonji, J. G., Arcidiacono, P., and Maurel, A. (2016). The Analysis of Field Choice in College and Graduate School: Determinants and Wage Effects. Handbook of the Economics of Education (5), Chapter 7.

Akerlof, G. A., and Kranton, R. E. (2000). Economics and Identity. The Quarterly Journal of Economics, 115(3), 715-753.

Akerlof, G. A., and Kranton, R. E. (2002). Identity and Schooling: Some Lessons for the Economics of Education. Journal of Economic Literature, 40(4), 1167-1201.

Anelli, M., and Peri, G. (2017). Peers' Composition Effects in the Short and in the Long Run: College Major, College Performance and Income. Economic Journal. 
Astorne-Figari, C., and Speer, J. D. (2017). Are Changes of Major, Major Changes? The Roles of Grades, Gender, and Preferences in College Major Switching. Unpublished Manuscript.

Baker, R., Bettinger, E., Jacob, B., and Marinescu, I. (2017). The Effect of Labor Market Information on Community College Students' Major Choice. NBER working paper, No. w23333.

Bertrand, M., Goldin, C., and Katz, L. F. (2010). Dynamics of the Gender Gap for Young Professionals in the Financial and Corporate Sectors. American Economic Journal: Applied Economics, 2(3), 228-255.

Bettinger, E. P., and Long, B. T. (2005). Do faculty serve as role models? The impact of instructor gender on female students. The American Economic Review, 95(2), 152157.

Booth, A. L., Cardona-Sosa, L., and Nolen, P. (2013). Do Single-Sex Classes Affect Exam Scores? An Experiment in a Coeducational University. IZA Discussion Paper, No. 7207.

Brenøe, A., and U. Zölitz (2017). Gender Peer Effects and the Gender Gap in STEM Specialization. Unpublished Manuscript.

Brown, C. and Corcoran, M., (1997). Sex-Based Differences in School Content and the MaleFemale Wage Gap. Journal of Labor Economics, 15(3), pp.431-465.

Bursztyn, L., Fujiwara, T., and Pallais, A. (2017). 'Acting Wife': Marriage Market Incentives and Labor Market Investments. American Economics Review, 107(11), pp.3288-3319.

Carrell, S. E., Page, M. E., and West, J. E. (2010). Sex and Science: How Professor Gender Perpetuates the Gender Gap. The Quarterly Journal of Economics, 125(3), 1101-1144.

Daymont, T. N., and Andrisani, P. J. (1984). Job preferences, college major, and the gender gap in earnings. Journal of Human Resources, 408-428. 
De Giorgi, G., Pellizzari, M. and Redaelli, S., (2010). Identification of Social Interactions Through Partially Overlapping Peer Groups. American Economic Journal: Applied Economics, 2(2), pp.241-75.

De Giorgi, G., Pellizzari, M. and Woolston, W.G., (2012). Class Size and Class Heterogeneity. Journal of the European Economic Association 10(4): 795-830.

Figlio, D. N. (2007). Boys Named Sue: Disruptive Children and Their Peers. Education, 2(4), 376-394.

Feld, J., Salamanca, N. and Hamermesh, D.S., (2016). Endophilia or Exophobia: Beyond Discrimination. The Economic Journal. 126, 1503-1527.

Feld, J. Salamanca, N. and Zölitz, U., (2017). Students are Almost as Effective as Professors in University Teaching. Melbourne Institute Working Paper Series, 23/17.

Feld, J. and U. Zölitz (2017). Understanding Peer Effects - On the Nature, Estimation and Channels of Peer Effects. Journal of Labor Economics. 35(2), 387-428.

Gerhart, B. (1990). Gender Differences in Current and Starting Salaries: The Role of Performance, College Major, and Job Title. ILR Review, 43(4), 418-433.

Goldin, C. (2014). A Grand Gender Convergence: Its Last Chapter. The American Economic Review, 104(4), 1091-1119.

Guryan, J., Kroft, K. and Notowidigdo, M., (2009). Peer Effects in the Workplace: Evidence from Random Groupings in Professional Golf Tournaments. American Economic Journal: Applied Economics 1(4): 34-68.

Hastings, J. S., Neilson, C. A., Ramirez, A., and Zimmerman, S. D. (2016). (Un) informed college and major choice: Evidence from linked survey and administrative data. Economics of Education Review, 51, 136-151.

Herfindahl, O. (1950). Concentration in the U.S. Steel Industry, Dissertation. New York: Columbia University. 
Hill, A. J. (2015). The Girl Next Door: The Effect of Opposite Gender Friends on High School Achievement. American Economic Journal: Applied Economics, 7(3), 147-177.

Hill, A. J. (2017). The Positive Influence of Female College Students on their Male Peers. Labour Economics, 44, 151-160.

Hirschman, Albert O. (1945) National Power and the Structure of Foreign Trade. Berkeley, CA: University of California Press.

Hoxby, C., (2000). Peer Effects in the Classroom: Learning from Gender and Race Variation. NBER working paper, No. w7867.

Kahn, S., and Ginther, D. (2017). Women and STEM. NBER working paper, No. w23525.

Kirkeboen, L. J., Leuven, E., and Mogstad, M. (2016). Field of Study, Earnings, and Selfselection. The Quarterly Journal of Economics, 131(3), 1057-1111.

Kugler, A. D., Tinsley, C. H., and Ukhaneva, O. (2017). Choice of Majors: Are Women Really Different from Men? NBER working paper, No. w23735.

Lavy, V. and A. Schlosser (2011). Mechanisms and Impacts of Gender Peer Effects at School. American Economic Journal: Applied Economics: 3(2), 1-33

Lee, S., Turner, L.J., Woo, S. and Kim, K., (2014). All or Nothing? The Impact of School and Classroom Gender Composition on Effort and Academic Achievement. NBER working paper, No. 20722.

Lordan, G., and Pischke, J. S. (2016). Does Rosie like Riveting? Male and Female Occupational Choices NBER Working Paper. No. w22495.

Machin, S., and Puhani, P. A. (2003). Subject of Degree and the Gender Wage Differential: Evidence from the UK and Germany. Economics Letters, 79(3), 393-400.

OECD (2016). Education at a Glance 2016: OECD Indicators, OECD Publishing.

Oosterbeek, H. and R. Van Ewijk (2014). Gender Peer Effects in University: Evidence from a Randomized Experiment. Economics of Education Review 38: 51-63. 
Sacerdote, B. (2001). Peer Effects with Random Assignment: Results for Dartmouth Roommates. The Quarterly Journal of Economics, 116(2), 681-704.

Sacerdote, B. (2014). Experimental and quasi-experimental analysis of peer effects: two steps forward?. Annual Review of Economics, 6(1), pp.253-272.

Schneeweis, N. and M. Zweimüller (2012). Girls, Girls, Girls: Gender Composition and Female School Choice. Economics of Education Review 31(4): 482-500.

Solnick, S. J. (1995). Changes in Women's Majors from Entrance to Graduation at Women's and Coeducational Colleges. Industrial and Labor Relations Review, 48(3), 505-514.

Thompson, J. S. (2003). The Effect of Single-sex Secondary Schooling on Women's Choice of College Major. Sociological Perspectives, 46(2), 257-278.

Whitmore, D. (2005). Resource and Peer Impacts on Girls' Academic Achievement: Evidence from a Randomized Experiment. American Economic Review, 199-203.

Wiswall, M., and Zafar, B. (2017). Preference for the Workplace, Investment in Human Capital, and Gender. Quarterly Journal of Economics, 133(1), pp.457-507.

Zafar, B. (2013). College Major Choice and the Gender Gap. Journal of Human Resources, 48(3), 545-595. 


\section{APPENDIX}

\section{A1 Data Restrictions}

Our sample period comprises the academic years 2009/10 until 2014/15. We derive our estimation sample in two steps. First, we exclude a number of observations from our estimation sample because they represent exceptions from the standard section assignment procedure. These exceptions are the same as documented in as in Feld, Salamanca and Zölitz (2017), who use data from the same environment and sample period. Second, we further limit our estimation sample to Business and Business Economics bachelor's programs which started in the academic years 2009/10 until 2011/12 because we can follow these cohorts from their first until their last bachelor's year and we observe their major choices.

Below we list the observations we exclude due to exceptions to the scheduling procedure.

- We exclude eight courses in which the course coordinator or other education staff actively influenced the section composition. One course coordinator requested to balance student gender across sections. The business school's scheduling department informed us about these courses.

- We exclude 21 sections from the analysis that consisted mainly of students who registered late to the course. Before April 2014, the business school reserved one or two slots per section for students that registered late. In exceptional cases where the number of late registration students substantially exceeded the number of empty spots, new sections were created that mainly comprise late registering students. This late registration policy was abolished in April 2014. 
- We exclude 46 repeater sections from the analysis. One course coordinator explicitly requests to assign repeater students who failed his courses in the previous year to special repeater sections.

- We exclude 17 tutorial groups that consisted mainly of students from a special researchbased program. For some courses, students in this program were assigned together to separate tutorial groups with a more-experienced teacher.

- We exclude 95 part-time MBA students since these students are typically scheduled for special evening classes with only part-time students.

- We exclude 4,274 student-year observations for students who were repeating courses. These students follow different attendance criteria and are graded under different standards.

- We exclude all observations of the first year and the first period students are observed. For these observations, we have no measure of previous performance of the student at the business school, an essential covariate in our analyses.

- We exclude all observations from the first teaching period of 2009 - the first period in our dataset - for the same reasons outlined above.

- We exclude 1,229 student-year observations from sections that take place after 6:30 p.m. since before fall 2015 students had the option to opt out of evening education, which makes the student assignment to these sections potentially non-random. 
Table A1: Alternative Randomization Check

\begin{tabular}{lcccccccc}
\hline Dependent Variable & \multicolumn{2}{c}{ Number Significant at the: } & \multicolumn{2}{c}{ Percent Significant at the: } & $\begin{array}{c}\text { Total } \\
\text { Number of } \\
\text { Courses }\end{array}$ & $\begin{array}{c}\text { Mean of p- } \\
\text { value }\end{array}$ \\
& $5 \%$ & $1 \%$ & $0.1 \%$ & $5 \%$ & $1 \%$ & $0.1 \%$ & 172 & 0.5250 \\
Female & 6 & 0 & 0 & $3 \%$ & $0 \%$ & $0 \%$ & 153 & 0.4685 \\
GPA & 8 & 2 & 0 & $5 \%$ & $1 \%$ & $0 \%$ & 0.5044 \\
Age & 8 & 4 & 0 & $5 \%$ & $2 \%$ & $0 \%$ & 175 & 0.5133 \\
ID Rank & 6 & 0 & 0 & $3 \%$ & $0 \%$ & $0 \%$ & 175 & 0.45 \\
\hline
\end{tabular}

NOTE.-This table is based on separate OLS regressions with gender, GPA, age and ID rank as dependent variables. The explanatory variables are a set of section dummies and dummies for the other parallel course taken at the same time and the nationality indicators German and Dutch. Columns (2) and (3) show in how many regressions the F-test on joint significance of all included section dummies is statistically significant at the 5 percent and 1 percent level, respectively. Columns (5) and (6) show for what percentage of the regressions the Ftest rejected the null hypothesis at the respective levels. Differences in number of courses reported in Column (1) are due to missing observations for some of the dependent variables. We do not include German and Dutch as dependent variables since these variables are mechanically balanced due to the stratification of assignment by nationality. For more detailed explanation of this randomization check see Feld and Zölitz (2017). 
Table A2: Testing for Attrition and Selective Survey Response

\begin{tabular}{|c|c|c|c|c|}
\hline Dependent Variable: & Study Dropout & $\begin{array}{c}\text { (2) } \\
\text { Observing } \\
\text { Student } \\
\text { Working on the } \\
\text { labor market }\end{array}$ & $\begin{array}{c}\text { (3) } \\
\text { Labor Market } \\
\text { Survey } \\
\text { Response }\end{array}$ & $\begin{array}{c}\text { (4) } \\
\text { Teaching } \\
\text { Evaluation } \\
\text { Survey } \\
\text { Response }\end{array}$ \\
\hline Female $*$ Proportion female peers & $\begin{array}{c}-0.0289 \\
(0.026)\end{array}$ & $\begin{array}{c}-0.0203 \\
(0.039)\end{array}$ & $\begin{array}{c}-0.0310 \\
(0.039)\end{array}$ & $\begin{array}{c}-0.0460 \\
(0.037)\end{array}$ \\
\hline Male $*$ Proportion female peers & $\begin{array}{l}0.0044 \\
(0.019)\end{array}$ & $\begin{array}{l}0.0175 \\
(0.030)\end{array}$ & $\begin{array}{l}0.0044 \\
(0.030)\end{array}$ & $\begin{array}{l}0.0044 \\
(0.030)\end{array}$ \\
\hline Female & $\begin{array}{l}0.0192 \\
(0.017)\end{array}$ & $\begin{array}{l}0.0011 \\
(0.026)\end{array}$ & $\begin{array}{l}-0.0039 \\
(0.026)\end{array}$ & $\begin{array}{c}0.0785 * * * \\
(0.022)\end{array}$ \\
\hline $\begin{array}{l}\text { Observations } \\
\text { R-squared }\end{array}$ & $\begin{array}{c}15,654 \\
0.535\end{array}$ & $\begin{array}{c}29,211 \\
0.123\end{array}$ & $\begin{array}{c}29,211 \\
0.121\end{array}$ & $\begin{array}{c}29,211 \\
0.123\end{array}$ \\
\hline
\end{tabular}

NOTE. - The dependent variables in Columns (1) is a dummy variable that equals 1 if we observe a student in a compulsory course but we do not observe their major or elective course choice. The dependent variables in Column (2) equals 1 if student responds to our graduate survey and reports that they are working. The dependent variables in Columns (3) and (4) are dummy variables which are equal to 1 if students responded to the respective survey. All Columns are estimated with ordinary least squares regressions that include course-times-year fixed effects, parallel course fixed effects, female, Std. GPA, Dutch and German. Robust standard errors using two-way clustering at the student and section level are in parentheses. ${ }^{*} \mathrm{p}<0.1, * * \mathrm{p}<0.05, * * * \mathrm{p}<0.01$. 
Table A3: Differences between Respondents and Non-respondents

\begin{tabular}{|c|c|c|c|c|c|c|}
\hline & \multicolumn{2}{|c|}{$\begin{array}{c}\text { Respondents } \\
(\mathrm{N}=1,388)\end{array}$} & \multicolumn{2}{|c|}{$\begin{array}{l}\text { Non-respondents } \\
\quad(\mathrm{N}=2,225)\end{array}$} & \multirow[b]{2}{*}{$(5)$} & \multirow[b]{2}{*}{ (6) } \\
\hline & (1) & (2) & (3) & (4) & & \\
\hline & Mean & $\mathrm{Sd}$ & Mean & $\mathrm{Sd}$ & $\begin{array}{l}\text { Difference } \\
\text { in Means }\end{array}$ & [p-value] \\
\hline Female-dominated Major & 0.287 & 0.452 & 0.296 & 0.457 & -0.009 & 0.677 \\
\hline Male-dominated Major & 0.179 & 0.384 & 0.200 & 0.400 & -0.021 & 0.430 \\
\hline Female & 0.406 & 0.491 & 0.374 & 0.484 & 0.032 & 0.002 \\
\hline Dutch & 0.215 & 0.411 & 0.284 & 0.451 & -0.069 & 0.000 \\
\hline German & 0.594 & 0.491 & 0.561 & 0.496 & 0.033 & 0.004 \\
\hline Age & 19.60 & 1.577 & 19.67 & 1.637 & -0.070 & 0.002 \\
\hline First Year GPA & 6.983 & 1.053 & 6.705 & 1.128 & 0.278 & 0.000 \\
\hline
\end{tabular}

NOTE.- 'Sd' refers to the standard deviation of the respective variable. p-values in Column (6) are obtained from bivariate regressions of a response dummy ( 1 if responded to graduate survey) on student characteristic. 
Table A4: Summary Statistics Labor Market Outcomes

\begin{tabular}{|c|c|c|c|c|c|c|}
\hline & (1) & (2) & (3) & (4) & (5) & (6) \\
\hline & \multicolumn{2}{|c|}{ All Students } & \multicolumn{2}{|c|}{ Female Students } & \multicolumn{2}{|c|}{ Male Students } \\
\hline & Mean & $\mathrm{Sd}$ & Mean & $\mathrm{Sd}$ & Mean & $\mathrm{Sd}$ \\
\hline First Earnings (in thousand $€$ per Year) & 41.78 & 38.81 & 38.73 & 36.56 & 43.56 & 39.99 \\
\hline Current Earnings (in thousand $€$ per Year) & 45.96 & 38.15 & 40.44 & 28.13 & 49.27 & 42.71 \\
\hline Working Hours & 48.04 & 11.77 & 45.63 & 10.59 & 49.46 & 12.21 \\
\hline Working Part Time & 0.04 & 0.20 & 0.05 & 0.22 & 0.04 & 0.19 \\
\hline Working over 60 Hours per Week & 0.36 & 0.48 & 0.35 & 0.48 & 0.37 & 0.48 \\
\hline Hourly Wage & 19.43 & 13.02 & 17.83 & 10.74 & 20.38 & 14.12 \\
\hline Job Satisfaction & 8.11 & 1.44 & 8.03 & 1.45 & 8.15 & 1.43 \\
\hline Subjective Social Impact of Job & 6.54 & 3.09 & 6.79 & 3.01 & 6.40 & 3.13 \\
\hline Male-dominated Job & 0.34 & 0.48 & 0.26 & 0.44 & 0.39 & 0.49 \\
\hline Finance or IT Job & 0.27 & 0.44 & 0.15 & 0.36 & 0.34 & 0.47 \\
\hline Female-dominated Job & 0.04 & 0.21 & 0.08 & 0.27 & 0.02 & 0.14 \\
\hline Marketing or HR Job & 0.12 & 0.33 & 0.17 & 0.38 & 0.09 & 0.30 \\
\hline
\end{tabular}

NOTE. - 'Sd' refers to the standard deviation of the respective variable. 
Table A5: Labor Market Outcomes: Variables and Survey Questions

\begin{tabular}{|c|c|c|}
\hline Variable & Survey Question & Answer Options \\
\hline $\begin{array}{l}\text { First Earnings per } \\
\text { Year }\end{array}$ & $\begin{array}{l}\text { Looking back at your first job after university, } \\
\text { what was your entry salary? What was your yearly } \\
\text { income before taxes? (including bonuses and } \\
\text { holiday allowances) }\end{array}$ & $0-1,000,000$ \\
\hline $\begin{array}{l}\text { Current Earnings per } \\
\text { Year }\end{array}$ & $\begin{array}{l}\text { What is your yearly income before taxes from your } \\
\text { main job? (including bonuses and holiday } \\
\text { allowances) }\end{array}$ & $0-1,000,000$ \\
\hline Working Hours & $\begin{array}{l}\text { How many hours per week do you usually work in } \\
\text { your main job? (including overtime) }\end{array}$ & $0-120$ \\
\hline Working Part Time & What describes your current situation best? & $\begin{array}{l}\text { full-time employed; part-time employed; self- } \\
\text { employed; studying; looking for a job; other } \\
\text { (please specify) }\end{array}$ \\
\hline $\begin{array}{l}\text { Working over } 60 \\
\text { Hours per Week }\end{array}$ & $\begin{array}{l}\text { How many hours per week do you usually work in } \\
\text { your main job? (including overtime) }\end{array}$ & $0-120$ \\
\hline Hourly Earnings & $\begin{array}{l}\text { calculated from current earnings and working } \\
\text { hours }\end{array}$ & \\
\hline Job Satisfaction & $\begin{array}{l}\text { How satisfied are you, all in all, with your current } \\
\text { work? }\end{array}$ & $\begin{array}{l}\text { 10-point scale; } 1 \text { "Totally unsatisfied" - } 10 \\
\text { "Totally satisfied" }\end{array}$ \\
\hline $\begin{array}{l}\text { Subjective Social } \\
\text { Impact of Job }\end{array}$ & $\begin{array}{l}\text { What do you think is the social impact of your } \\
\text { current work? }\end{array}$ & $\begin{array}{l}\text { 11-point scale ranging from }-5 \text { "Very negative } \\
\text { social impact" over } 0 \text { "Neutral, no social impact" } \\
\text { to }+5 \text { "Very positive social impact" }\end{array}$ \\
\hline Male-dominated Job & $\begin{array}{l}\text { What is the share of male co-workers in percentage } \\
\text { at your hierarchy level? }(0 \% \text { means none of your } \\
\text { co-workers are male; } 100 \% \text { means all of your co- } \\
\text { workers are male) }\end{array}$ & $0-100 \%$ \\
\hline Finance or IT Job & $\begin{array}{l}\text { Which of the following keywords describe your } \\
\text { current job tasks? }\end{array}$ & $\begin{array}{l}\text { Marketing or Advertising of Goods or Services; } \\
\text { Finance, Banking, Trading or Insurance; } \\
\text { Accounting; Supply Chain Management, } \\
\text { Logistics and Transportation; } \\
\text { Telecommunications, Information Technology } \\
\text { (IT), Internet; Human Recourses Management; } \\
\text { Health or Pharma; Management Consultancy; } \\
\text { None of the above fits (please specify other } \\
\text { keywords): }\end{array}$ \\
\hline $\begin{array}{l}\text { Female-dominated } \\
\text { Job }\end{array}$ & $\begin{array}{l}\text { What is the share of male co-workers in percentage } \\
\text { at your hierarchy level? }(0 \% \text { means none of your } \\
\text { co-workers are male; } 100 \% \text { means all of your co- } \\
\text { workers are male) }\end{array}$ & $0-100 \%$ \\
\hline $\begin{array}{l}\text { Marketing or HR } \\
\text { Job }\end{array}$ & $\begin{array}{l}\text { Which of the following keywords describe your } \\
\text { current job tasks? }\end{array}$ & $\begin{array}{l}\text { Marketing or Advertising of Goods or Services; } \\
\text { Finance, Banking, Trading or Insurance; } \\
\text { Accounting; Supply Chain Management, } \\
\text { Logistics and Transportation; } \\
\text { Telecommunications, Information Technology } \\
\text { (IT), Internet; Human Recourses Management; } \\
\text { Health or Pharma; Management Consultancy; } \\
\text { None of the above fits (please specify other } \\
\text { keywords): }\end{array}$ \\
\hline
\end{tabular}

NOTE._- "Working Part Time" is an indicator variable that equals one if graduates indicated the answering option "part time employed." "Working over 60 Hours per Week" is an indicator variable that equals one if graduates reported more than 60 hours. "Male-dominated Job" is an indicator variable that equals one if graduates reported a percentage of male co-workers higher than 75 percent. "Finance or IT Job" is an indicator variable that equals one if graduates either selected one of the two options "Finance, Banking, Trading or Insurance" or "Telecommunications, Information Technology (IT), Internet." "Femaledominated Job" is an indicator variable that equals one if graduates reported a percentage of male co-workers lower than 25 percent. "Marketing or HR Job" is an indicator variable that equals one if graduates either selected one of the two options "Marketing or Advertising of Goods or Services" or "Human Recourses Management." 
Table A6: The Impact of Gender Composition on Other Job Characteristics

\begin{tabular}{|c|c|c|c|c|c|c|}
\hline Dependent Variable: & $\begin{array}{c}\text { (1) } \\
\text { Working } \\
\text { Part Time }\end{array}$ & $\begin{array}{c}(2) \\
\text { Working } \\
\text { over } 60 \\
\text { Hours } \\
\text { per } \\
\text { Week }\end{array}$ & $\begin{array}{c}\text { (3) } \\
\text { Male- } \\
\text { dominated } \\
\text { Job }\end{array}$ & $\begin{array}{c}(4) \\
\text { Female- } \\
\text { dominated } \\
\text { Job }\end{array}$ & $\begin{array}{c}\text { Finance or IT } \\
\text { Job }\end{array}$ & $\begin{array}{l}\text { Marketing } \\
\text { or HR Job }\end{array}$ \\
\hline Female * Proportion Female Peers & $\begin{array}{c}0.0705 * \\
(0.042)\end{array}$ & $\begin{array}{l}-0.0472 \\
(0.040)\end{array}$ & $\begin{array}{c}-0.1054 \\
(0.066)\end{array}$ & $\begin{array}{l}0.0124 \\
(0.038)\end{array}$ & $\begin{array}{c}-0.1192 * * \\
(0.057)\end{array}$ & $\begin{array}{l}0.0031 \\
(0.060)\end{array}$ \\
\hline Male * Proportion Female Peers & $\begin{array}{l}0.0272 \\
(0.025)\end{array}$ & $\begin{array}{c}0.0986^{* *} \\
(0.045)\end{array}$ & $\begin{array}{l}0.0082 \\
(0.057)\end{array}$ & $\begin{array}{l}-0.0001 \\
(0.019)\end{array}$ & $\begin{array}{l}0.0319 \\
(0.055)\end{array}$ & $\begin{array}{l}0.0178 \\
(0.044)\end{array}$ \\
\hline Female & $\begin{array}{l}-0.0095 \\
(0.021)\end{array}$ & $\begin{array}{l}-0.0071 \\
(0.030)\end{array}$ & $\begin{array}{c}-0.1197 * * \\
(0.049)\end{array}$ & $\begin{array}{l}0.0377 \\
(0.024)\end{array}$ & $\begin{array}{c}-0.1166 * * \\
(0.045)\end{array}$ & $\begin{array}{c}0.1228 * * * \\
(0.040)\end{array}$ \\
\hline Observations & 9,690 & 9,690 & 9,588 & 9,588 & 9,690 & 9,690 \\
\hline R-squared & 0.127 & 0.072 & 0.056 & 0.057 & 0.069 & 0.060 \\
\hline Mean Dependent Variable & .0511 & .0993 & .3458 & .0378 & .2894 & .1983 \\
\hline Mean Dep. Var. Women & .0555 & .0563 & .2473 & .0629 & .1803 & .2675 \\
\hline $\begin{array}{l}\text { Mean Dep. Var. Men } \\
\text { p-value of Test for Gender }\end{array}$ & .0482 & .1273 & .4097 & .0215 & .3604 & .1533 \\
\hline $\begin{array}{l}\text { Equality of Proportion Female } \\
\text { Peers }\end{array}$ & .4038 & .019 & .2318 & .795 & .0771 & 0.8543 \\
\hline
\end{tabular}

NOTE.- The dependent variable in Column (1) is a dummy variable which is equal to 1 if the respondent indicated to be working part time. The dependent variable in Column (2) is a dummy variable which is equal to 1 if the respondent indicated to be working over 60 hours per week. The dependent variable in Column (3) is a dummy variable which is equal to 1 if the respondent works in an environment with over 75 percent male coworkers. The dependent variable in Column (4) is a dummy variable which is equal to 1 if the graduate works in an environment with over 75 percent female co-workers. The dependent variable in Column (5) is a dummy variable equal to 1 if the former student indicated that she is working in the finance, banking or insurance sectors. The dependent variable in Column (6) is a dummy indicator which is equal to 1 if the respondent indicated that he/she is working in a marketing or advertising job. All Columns are estimated with ordinary least squares regressions that include course-times-year fixed effects, parallel course fixed effects, female, Std. GPA, Dutch, German and a dummy for whether the survey data was collected by phone interviews (as opposed to email). Differences in the number of observations are due to graduates refusing to answer specific questions. Robust standard errors using two-way clustering at the student and section level are in parentheses. $* \mathrm{p}<0.1, * * \mathrm{p}<0.05$, $* * * \mathrm{p}<0.01$. 
Table A7: Summary Statistics Student Course Evaluation Outcomes

\begin{tabular}{|c|c|c|c|c|c|c|c|}
\hline \multirow[b]{3}{*}{ Outcome } & \multirow[b]{3}{*}{ Scale } & \multirow{2}{*}{\multicolumn{2}{|c|}{$\begin{array}{l}(1) \\
\text { All Students }\end{array}$}} & (3) & (4) & (5) & (6) \\
\hline & & & & \multicolumn{2}{|c|}{$\begin{array}{r}\text { Female } \\
\text { Students }\end{array}$} & \multicolumn{2}{|c|}{$\begin{array}{c}\text { Male } \\
\text { Students }\end{array}$} \\
\hline & & Mean & $\mathrm{Sd}$ & Mean & Sd & Mean & $\mathrm{Sd}$ \\
\hline Course grade & $\begin{array}{l}1 \text { to } 10 \text { scale, } 10=\text { highest } \\
\text { grade }\end{array}$ & 6.583 & 1.715 & 6.660 & 1.669 & 6.530 & 1.743 \\
\hline $\begin{array}{l}\text { Please give an overall grade for the } \\
\text { quality of this course. }\end{array}$ & 1 to 10 scale, $10=$ very good & 7.070 & 1.843 & 7.011 & 1.764 & 7.118 & 1.903 \\
\hline $\begin{array}{l}\text { Working in tutorial groups with my } \\
\text { fellow-students helped me to better } \\
\text { understand the subject matters of } \\
\text { this course. }\end{array}$ & 1 to 5 scale, $5=$ totally agree & 3.966 & 0.941 & 3.985 & 0.965 & 3.951 & 0.921 \\
\hline $\begin{array}{l}\text { My tutorial group has functioned } \\
\text { well. }\end{array}$ & 1 to 5 scale, $5=$ totally agree & 3.918 & 0.961 & 3.898 & 0.984 & 3.933 & 0.942 \\
\hline
\end{tabular}

NOTE._- 'Sd' refers to the standard deviation of the respective variable. 
Figure A1: Alternative Randomization Check - Distribution of p-values
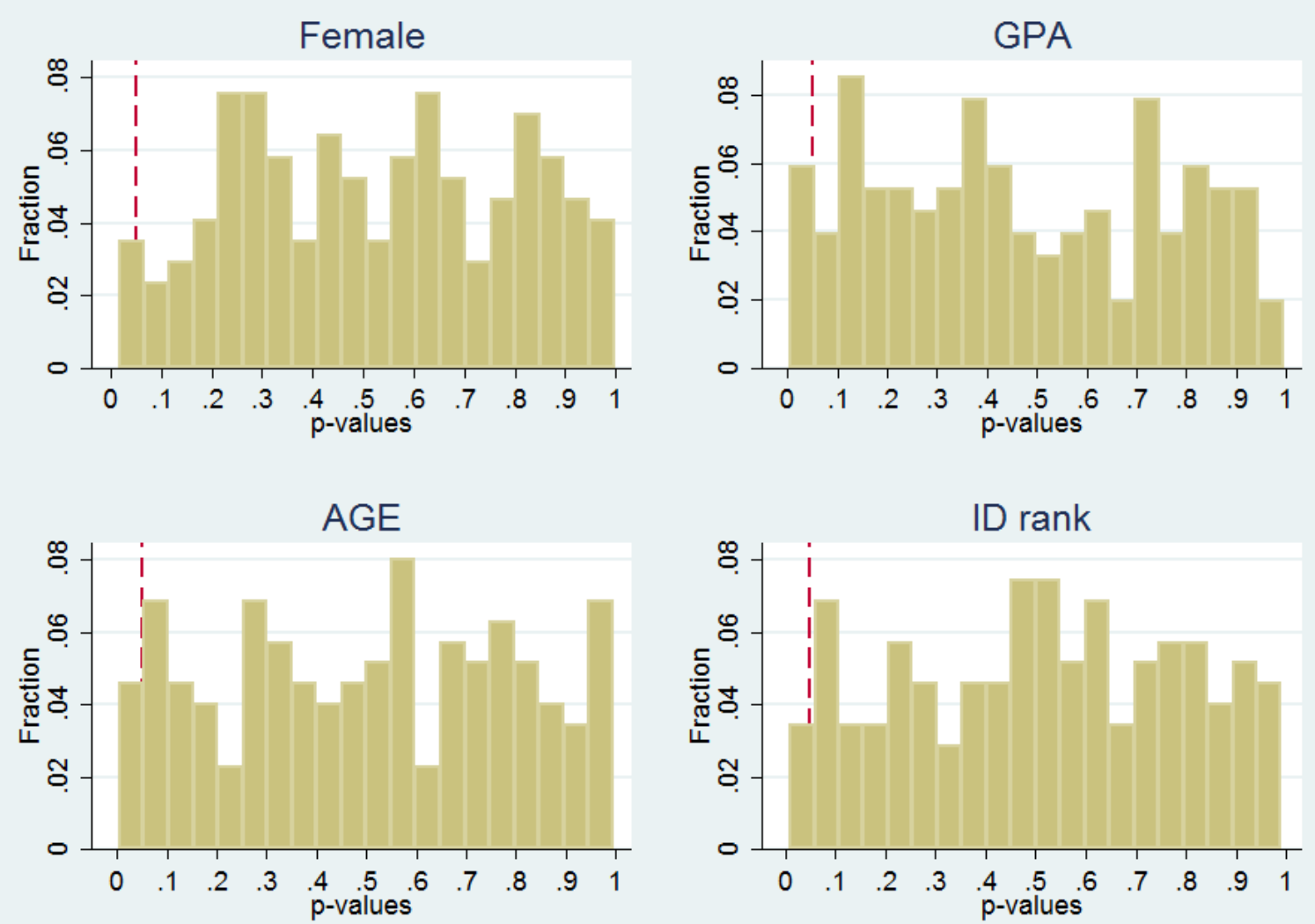

NOTE.-These are histograms with p-values from all the regressions reported in Table A1. The vertical line in each histogram shows the 5 percent significance level. 
Figure A2: Testing Non-Linear Effects Using Five Bins for Proportion Female Peers
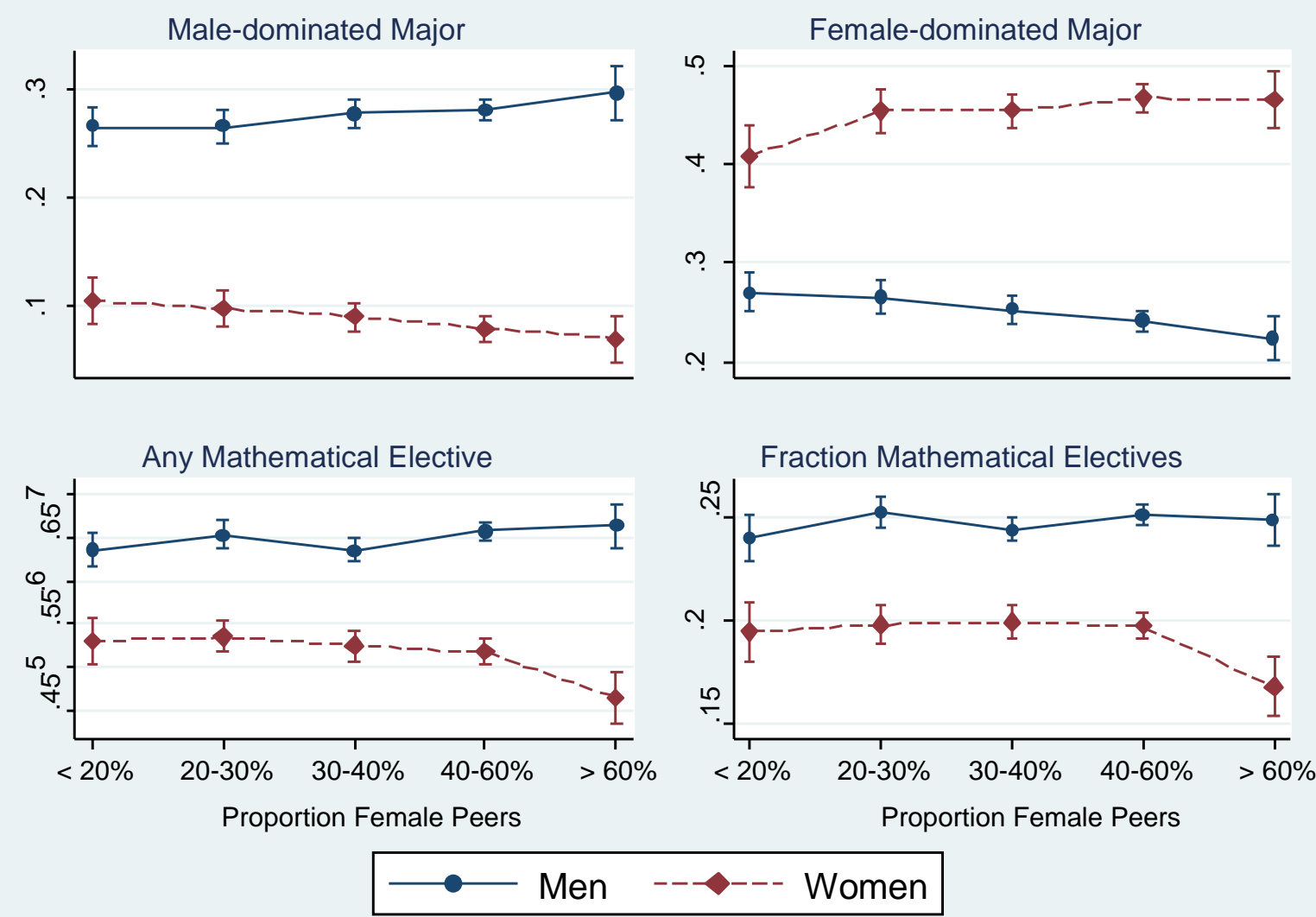

NOTE.- The figure shows marginal effects from OLS regression using five bins for the proportion of female peers. All regressions include course-times-year fixed effects, parallel course fixed effects, female, Std. GPA, Dutch and German as controls. For definitions of dependent variables see Table 4. Vertical lines represent 95 percent confidence intervals. 


\section{A2 Coordination of Major Choices}

In order to investigate whether students' coordination drive our results on major choice affects, we test whether the peer composition affects the diversity of major choice of students within a section. In order to measure diversity in major choice, we use the Blau diversity index (Blau, 1977), ${ }^{23}$ which can be written as follows:

$$
B_{s}=\left(1-\sum_{j=1}^{N} m_{j s}^{2}\right),
$$

where $m_{j s}$ represents the proportion of students in section $s$ that choose major $j$, and $N$ is the total number of different majors chosen in that section. $B_{s}$ is equal to 0 if all students in a given section choose the same major, then increases as heterogeneity in major choice grows, and is largest and closest to one when all majors attract an equal share of students. Intuitively, $B_{S}$ can be interpreted as the probability that two students drawn at random (with replacement) from the same section choose the same major. We construct the normalized Blau diversity index at the section level for all students and separately for all women and men in a section. The normalized Blau index corrects for the number of choice alternatives and can therefore reach any number between 0 and 1 independent of the number of choice alternatives. In order to estimate the effect of peer composition on diversity of major choice, we estimate the following model:

$$
\widetilde{B}_{s}=\beta_{1} \bar{F}_{s}+\widetilde{X}_{c} \tilde{\gamma}^{\prime}+\varepsilon_{s}
$$

where $\tilde{B}_{S}$ is the normalized Blau index for diversity of major choice in section $s, \bar{F}_{S}$ is the proportion of women in section $s, \widetilde{X}_{c}$ is a vector of course-year fixed effects and $\varepsilon_{s}$ is the error

\footnotetext{
${ }^{23}$ Note that the Blau diversity index is equal to the inverse of the Herfindahl-Hirschman Index (HHI) (Hirschman, 1945; Herfindahl, 1950).
} 
term. The parameter of interest is $\beta_{1}$, which shows the causal effect of increasing the share of women in a section on the diversity of major choice of students in that section.

Table A8 shows the estimates of the effect of the proportion of women in a section on the diversity of major choices for all students (Column 1), women (Column 2) and men (Column 3). We find a negative and statistically significant relationship between the proportion of women in a section and the overall Blau index, indicating that major choices become more homogeneous when more women are in the same section. This effect is entirely driven by an increased homogeneity in women's major choice. A 10-percentage point increase in the proportion of women raises the probability that two randomly chosen women in the same section have chosen the same major by 1.12 percentage points. This increase in homogeneity is consistent with women coordinating their major choice. Alternatively, women may find majors more attractive if more other women plan to take them. The diversity of men's major choices is not significantly affected.

Table A8: The Impact of Gender Composition on Diversity in Major Choice

\begin{tabular}{lccc}
\hline Dependent Variable: & $\begin{array}{c}(1) \\
\text { Normalized Blau } \\
\text { Diversity Index, } \\
\text { all Students }\end{array}$ & $\begin{array}{c}(2) \\
\text { Normalized Blau } \\
\text { Diversity Index, } \\
\text { Female Students }\end{array}$ & $\begin{array}{c}(3) \\
\text { Normalized Blau } \\
\text { Diversity Index, } \\
\text { Male Students }\end{array}$ \\
\hline Proportion Female Students in Section & $-0.0227^{* *}$ & $-0.1133^{* * *}$ & 0.0137 \\
& $(0.011)$ & $(0.013)$ & $(0.016)$ \\
Observations & & 2,004 & 2,004 \\
R-squared & 2,004 & 0.157 & 0.441 \\
Mean Dependent Variable & 0.550 & 0.930 & 0.906 \\
\hline
\end{tabular}

NOTE.- The dependent variables in all Columns is the normalized Blau diversity index, which is constructed based on the major choices in the given section. All Columns are estimated with ordinary least squares regressions that include course-times-year fixed effects. In this table, we restrict the estimation to sections that contain at least two women and two men since we need at least two women (men) to calculate the Blau index for female (male) students. Robust standard errors clustered at the course level are in parentheses. $* \mathrm{p}<0.1, * * \mathrm{p}<0.05, * * * \mathrm{p}<0.01$. 